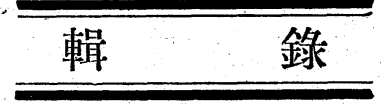

\title{
金屬の酸化，腐蝕に對する電子迴折的研究 (II)
}

\section{（4）その他の金風，合金による酸化}

$\mathrm{Ni}$ の酸化物 $\mathrm{NiO}$ は X 線によれはば格子常數 $4.17 \AA$ の 岩監型結晶であるが, Darbyshire(2), Davisson と Germer ${ }^{(69)}$; Preston ${ }^{(60)}$, Smith $^{(4)}$ ，三宅 ${ }^{(46)}$ 等の電子廻折に上る結 果も大體これに符號する。たよ゙しDarbyshireは電解法によ つて得た酸化膜の゙透過により $a=4.10 \mathrm{~A}$ を，Prestonは 研磨した $\mathrm{Ni}$ 板の酸化面の反射像加ら $a=4.10 \AA$ を, Smith は干涉色を呈する酸化面加電解法に上つて得忐綠色透明 の薄膜から $a=4.18 \AA$ を，三宅は $400 \sim 900^{\circ}$ に加熱酸化 した $\mathrm{Ni}$ 面の反射により $a=4.16 \mathrm{~A}$ を得て抢り，1格子常 數値に若干の變動汃見られるが，これはむしろ測定裝置の 進步に歸すべきか子知れない。

Beeching(35) は Cr の具空蒸着膜を反射で調べたが，膜 の厚さが小なる時，金屬自體による外に酸化物による迴折 環を得，また膜が厚いときは Cr 迴折環の久を得たが，加 熱によつて前同樣の酸化物迴折環を得た。これ等酸化物は $a=5.46 \AA ̊ ̊ 0 \mathrm{Cr}_{2} \mathrm{O}_{3}$ と認められる. 三宅(46) によれば $\mathrm{Cr}$ の加等表面には $700^{\circ}$ 以上で $\mathrm{Cr}_{2} \mathrm{O}_{3}$ が生ずるが， $600^{\circ}$ 以 下では微結晶質となり環がばやける. $\mathrm{Cr}_{2} \mathrm{O}_{3}$ の迴折環は $\alpha$ $\mathrm{Fe}_{2} \mathrm{O}_{3}$ に類似した三方晶迴折環であるが $\alpha=54^{\circ} 50^{\prime}$ ( X 線 データー) とすると $a=5.32 \AA$ (X 線では $a=5.38 \AA$ )を 得た。

$\mathrm{Ni}$ と $\mathrm{Cr}$ との合金で實用上用涂の廣いニクロムは $\mathrm{Ni}$ 80-Cr 20 の組成を有する高溫度で酸化し䧼い合金である

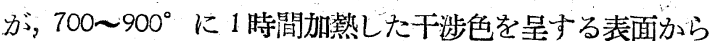
は $a=8.32 \AA$ のスピネル型建折像か得られ(46)(61), 三宅に よれば恐らく $\mathrm{NiCr}_{2} \mathrm{O}_{4}$ (X線によ机ば $a=8.30 \AA$ ) である らと考えられる.な物このものでは (100) または (511) が表面に平行になる方向性が得られた。 X線によつて检出 されるニクロムの酸化物は, $\mathrm{Cr}_{2} \mathrm{O}_{3}, \mathrm{NiO}$ 及びごく少量の $\mathrm{NiCr}_{2} \mathrm{O}_{4}$ とより成るが，これ等と電子迴折との相違は恐ら く檢出される梁さに関係があると思われる. Lかし戰後の 研究(62) によると不純物含有量によつて酸化物の種類が異

* 東北大學呚授; 金屬材料研究所

(59) C. J. Davisson and 'L. H. Germer, Phys. Rev., $40(1932), 124$.

(60) G. D. Preston, Phil. Mag., 17 (1934),466.

(61) I. Iitaka and S. Miyake, Nature, 137 (1936), 457.

(62) J.W. Hickman and E. A. Gulbransen, A.I. M. M. E. Inst. Metals Div. Metals Techn., 15 (1948), 15
小川四 郎*

なるようにも考えられる. 即ち通常の二クロム酸化物は $\mathrm{Cr}_{2} \mathrm{O}_{3}$ であるが,少量の $\mathrm{Si}$ の添加によつて二クロムの壽命 が長くなり同時に表面酸化物は $\mathrm{NiO} \cdot \mathrm{Cr}_{2} \mathrm{O}_{3}$ 即ち $\mathrm{NiCr}_{2} \mathrm{O}_{4}$ となる。

Hastelloy はNi，M，Fe を主成分とする酎熱合金であ るが, Hickmann と Gulbransen(63) との詳しい研究に よると, Ni 55 60, Mo 15 20, Fe 15 20, 0.15 0.20 を含むもの (A) では $900^{\circ}$ 迄の表面酸化物は スピネル型 の $\mathrm{Fe}_{3} \mathrm{O}_{4}$ であり, $\mathrm{Ni}, \mathrm{M}_{0}$ の酸化物は生ぜず $\mathrm{Fe}$ の酸化速 度が優越している. Ni 60〜 65, Mo 25〜35, Fe 5 を含むも の (B) は $500^{\circ}$ 迄は $\mathrm{NiO}$ が表面に生じ，600 では少量 の $\mathrm{MoO}_{3}$ を含も $\mathrm{M}_{0} \mathrm{O}_{2}$ が, $700^{\circ}$ では スピネル 型酸化物 (恐らく $\mathrm{Fe}_{3} \mathrm{O}_{4}$ ) が生ずる. $800^{\circ}$ 短時間の酸化では同じく スピネル型酸化物が，長時間では $\mathrm{NiO}$ が生じ，900 では 始めは $\mathrm{MoO}_{22}$, 長時間後にスピネル酸化物（恐らく $\mathrm{NiO}$. $\mathrm{Fe}_{2} \mathrm{O}_{3}$ ) が生ずる. Ni 55 60, Mo 15〜20, Fe 6, Or 12 16,W 5 のもの (C) では $\mathrm{Cr}$ の存在のために $600^{\circ}$ 以上で特 に耐酸化性が大であるが, $500^{\circ}$ 迄は $\mathrm{Fe}_{3} \mathrm{O}_{4}, 600$ 〜 $70^{\circ}$ で $\mathrm{Cr}_{2} \mathrm{O}_{3}, 800^{\circ}$ 短時間では $\mathrm{Cr}_{2} \mathrm{O}_{3}+\mathrm{MoO}_{2}$, 長時間後に $\mathrm{NiO}$. $\mathrm{Cr}_{2} \mathrm{O}_{3}$ が生じ $900^{\circ}$ でも大體同樣な傾向にある. $\mathrm{Ni} 85, \mathrm{Cu}$ 3, Si 10,A1 2 の Hastelloy D は Si を相當量含むにも拘 らず $600^{\circ}$ 迄は $\mathrm{Cu}_{2} \mathrm{O}, 700$ 〜00 では $\mathrm{NiO}$ が生ずるのみ で Si の酸化物は表面に見られなかつた. 恐らくSi 酸化物 が無定形であるか，または金屬地に密着して表面反射に與 らないのであうう. Hickmann と Gulbransen はこのよ $5 に \mathrm{Fe}, \mathrm{Co}, \mathrm{Ni}, \mathrm{Cr}$ 等を含寻代表的な 各種合金の300 $700^{\circ}$ に特ける酸化を研究し次のよう尔綜合的結果(64) を得 た. 即ち他の元素に比べて Fe 及び $\mathrm{Cr}$ はより容易に表面 に擴散し易く、ニクロム $\mathrm{V}$ やインコネルのように多量の $\mathrm{Ni}$ を含む場合にも $\mathrm{NiO}$ は表面に生ぜず，また $\mathrm{CoO}$ は 低溫度の酸化に特いてて筧測され, $\mathrm{Fe}, \mathrm{Cr}$ 以外の金屬で 合金成分の $5 \%$ 以下しか占めないような成分のものは單純 な酸化物としてでなく他の金屬と共同して酸化物を作る. また表面が浸され難い耐熱的合金では酸化層は一定の構造 を有せず，例えば $\mathrm{Cr}_{2} \mathrm{O}_{3}$ や XO· $\mathrm{Y}_{2} \mathrm{O}_{3}$ 型のスピネルやそれ 等の混合物户または $\mathrm{CoO}$ を生ずることが多い。

$\mathrm{ZnO}$ の薄膜は數多くの銃い,迴折環を生じ，美麗なる廻

(63) J. W. Hickman ànd E. A. Gulbransen, J. Phys. Colloid. Chem., 52 (1948),1186.

(64) J.W. Hickman and E.A. Gulbransen, A.I. M. M. E. Inst. Me ${ }^{\star}$ als Div. Metals Techn., 13 (1946), 27. 
折像を示するのの一つである. Bragg と Darbyshire(65) は Thomsonの示唆によつて熔融 Zn から銅環によつて透 明な酸化膜を得たが，その迴折像は六方格子に對應せずむ しろ $a=4.62 \mathrm{~A}$ の格子常數を有する 閃亞鉆鑛型の立方格 子に相當するものであつた 但し (111)及び (200) 迴折環 の徑が計算値よら相當小さく加う(110), (321) 等の消える へき指數のものが出て乱り疑問の餘地がある. 然し Zn ま たは六方 ZnO の强度大なる迴折環が存在しないからこれ 等には該當しないと報告している. Otty(66) も同樣な方法 で ZnO 薄を作つたが，但し銅環をまず鲖酸で洗つた後に Z $\mathrm{nCI}$ 溶液中に入れてこれを flux とした. 彼の得た結果 は X 線で確められた通常の六方 格子を有する $\mathrm{ZnO}$ でそ のc 軸を表面に垂直にするるのであつた. Darbyshire と Cooper ${ }^{(32)}$ が同樣な方法で作うた $\mathrm{ZnO}$ 薄膜は Bragg と Darbyshire とが得たような立方格子と見間違う樣なるの であつたが，彼等の研究ではこれは立方格子ではなく六方 格子が特別な方性を持つた結果であつて，從つて Bragg と Darbyshire の場合の疑問も解决されたわけでする.

Finch と Quarrell(67)(68) は迴折カメラ中で $\mathrm{Zn}, \mathrm{Al}, \mathrm{Mg}$ 等を $\mathrm{Pt}$ 上に蒸着して空氣酸化をせしめた後反射泆で，ま たは酸化せる蒸着膜を透過法で.調べたが, ZnOについて 得られた結果は甚だ與味あるすのであつた. 即ち Pt 上に 蒸着した ものでは $a=2.63 \stackrel{\mathrm{A}}{,} c=2.58 \AA$ の六方晶が得ら れ, $\mathrm{X}$ 線データーの゙ $a=3.22 \AA, c / a=1.61 \AA$ 之著しい對比 を示した：透過法による場合には測定の精確を期するた めに標凖物質として正常な構造を 有する $\mathrm{ZnO}$ 膜を選び double shutter法で撮影したが，ある場合にはPt 上に特 けると同樣序“假晶” (Pseudomorphism) が Zn 及び正 常 $\mathrm{ZnO}$ と共存して得られた. 與味あることはこの“假晶” の $a$ の價は $2.686 \AA$ 它 Zn の $a=2.686 \AA$ と全く一致す ることである. Finch と Quarrell の說明によれば，Zn の酸化に當つて酸化膜が非常に薄い間は金屬 $Z n$ の影響 を受け，先の六方底面に猢る原子配置を保存しつっ Zn が成長する結果であつて，酸化膜の厚さが大になればこの よ弓な “假晶”を起寸歪力は減少し正常な ZnO の構造に 杘るのである “假晶”に関する彼等の研究では，室溫酸化 を續ける限りは巽常構造の ZnO の夕が得られ，これを加 熱すれば正常な ZnO の發達が見られるけれども金屬 Zn との間には体然として “假晶”が存在する. また Znが單 結晶ならば翼常 $\mathrm{ZnO}$ も單結晶であるが，正常 $\mathrm{ZnO}$ は多 結晶である. 單結晶でも ZnO の六方底面は膜面に平行で

(65) W.L. Bragg and J.A. Darbyshire, Trans. Far. Farady Soc., 28 (1932), 522.

(66) Otty, unpublished, G.P. Thomson and W: Cochrane, Theory and Practice of Electron Diffraction, P. 180.

(67) G.I. Finch and A.G. Quarrell, Proc. Roy. Soc., 141 (1933),398.

(68) G. I. Finch and A. G. Quarrell, Proc. Phys. Soc. $, 46(1934), 148$.
ある. 以上の結果からいえることは, ZnO は元來酸化し易 い金屬であるがその表面に生ずる異常構造を有する ZnO “假晶”が稠密構造を有し酸素の貫入を防ぐために酸化の進 行を防止する結果となる，その後 Jenking(69) は他の數種 の金屬と共に Zn 熔融面を反射法で調べたが，その (001) 面は常に愹融表面に本行となつて呿り， ZnOは $a=3.22$ $\mathrm{A}, c=5.18 \mathrm{~A}$ の格子常數を有する正常なものであつ庆. さらに愹融面上の酸化物は電子光學的に本滑であり從つて 反射洗に括いてては屈折效果を起し內部內位を測定すること が出來る. ZnOについての゙價は $12.3 \mathrm{~V}$ であつた、戰後 Raether(70) は Zn 單結晶の酸化を研究したが，(001) 䢃 開面では室溫に打いて酸化物の平行成長が見られその厚さ

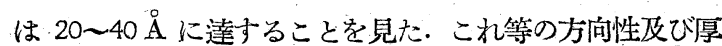
さは乾燥せる空氣中に長く放置しても不變であつた。この 場合にも酸化物の表面は電子光學的に平滑であつて，屈折

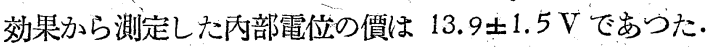
溫度を高めると酸化物の厚さは增大乚最早單結晶的成長を とらず針狀の微結晶より成る粉未形結晶となる。な招 $\mathrm{Zn}$ 蒸着膜を觀察したが，Znの厚さが 50〜100 ̊ の場合に 弱い迴折環を示寸酸化物が存在した. ZnO に関寸る研究 で異色のあるのは上田と紀本(71) による亞鉆某の研究であ る. 亞鉆某は $1 \mu$ 以上の波長を有する赤外線に對する吸收 が大であつて，從つて赤外線用熱電對の吸收膜の黑化に用 いられるのであるが，この研究は電子迴折によつて煤の本 性を明かにするために行われたものである.10-3〜760 mm Hg の種々の空氣壓中で W 線涤を加熱してその中に置い た Zn 箔を蒸發して煤を作るのであるが，生成物の色及び 廻折像は壓力と共に非常に變化し，画折像は大凡 5 種類の 型に分類される．氣壓が大である時は蒸發煙は白色で迴折 像は大體 Debye 環でありその面間隔は ZnO の X 線デ ーターとよく一致し結晶粒の大さは $200 \AA$ より大である。 が, 氣壓が低下するにつれて蒸發煙の色は灰, 茶, 群青, 黑色等に變化しぼやけた環と銃い、環とを示すようになる。 前者は細かい $\mathrm{WO}_{3}$ であつて後者は金屬 $\mathrm{Zn}$ の環であつた。 眮空度が高くなるとZnの結晶粒の大さは增大寸る.從 つて實際に ZnO の煤を生ずるのは 760 30 mm Hg の氣 壓範園であつた。

Cd の酸化物 (32) は熔融金屬上から loop 法によつて取り 出したものについて調べられたの久であるが，熔融金屬の 溫度を熔融點の少しく上に保つた時得られる酸化物の色は

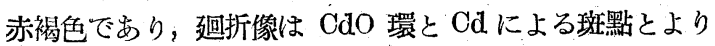
成る. $\mathrm{CdO}$ の格子常數は X線データー $-(a=4.70 \mathrm{~A})$ と良 く一致し，その强度は岩䜿型構造として說明せられ閃亞鉛 鑛型とは異つていたが, 完全に岩監型といらには計算と測 定に若干の差があつた。

$\mathrm{Sn}$ の酸化物は $\mathrm{SnO}$ \& $\mathrm{SnO}_{2}$ も正方晶であるが, Stei-

(69) R.O. Jenkins, Proc. Phys. Soc., 47 (1935), 109.

(70) H. Raether. J. Phys. Radium, 11 (195), 11 . （71）上田良二，紀本和男，應用物理，18(1949/50),? 
nheil(29) によれば, Sn 膜の G-加熱による酸化では $a=$ 3. $77 \mathrm{~A}, c=4.77 \mathrm{~A}$ の $\mathrm{SnO}$ と $a=4.72 \mathrm{~A}, c=3.17 \mathrm{~A}$ の $\mathrm{SnO}_{2}$ とが混合して生じ，場合によつて一方が優勢にな る. Jenking( ${ }^{(69)}$ は熔瀜 Sn 上から得た表面膜の透過に上 つて $\mathrm{SnO} の(001)$ が膜面に本行になつていることを見た が，その際熔融 $\mathrm{Sn}$ の溫度を更に上げると $\mathrm{SnO}_{2}$ の膜を得 た. 愹融面上の区射では $\mathrm{SnO}$ の像を得たが $(a=3.80 \mathrm{~A}$, $c=4.81 \mathrm{~A}), \mathrm{ZnO}$ の場合と同樣に內部の電位を測定するこ とが出來，14.2 V の價を得ている. Bragg と Darbyshire (65) が $\mathrm{Sn}$ 䇴のガス陷による酸化で得た酸化物は $\mathrm{SnO}_{2}$ で あつて $a=4.72 \AA ， c=3.17 \AA$ と報告している.

$\mathrm{Sb}$ の酸化物は Darbyshire と Cooper(32) 方溶融金屬 から loop 法で取ることを試みたが成功せず，1％Mg を 添加したもの加ら得られた趈折像は $\mathrm{MgOKL}$ に备折環と 金屬 $\mathrm{Sb}$ に上る斑點像とであつて $\mathrm{Sb}$ 酸化物の廻折環は見 出されなかつた。

Ba の酸化に関しては Burgers と Amstel(72) の研究が ある. カメラ中で $\mathrm{Cu}$ 研磨面に Ba せた. 蒸着 Baは は(111) 面を表面に本行にする方向性を もち，その上に生じた $\mathrm{BaO}$ は (110)面が表面に本行にな る. 但し [110] が [100] 方向人 10 15 位傾むいてい る. この方向性は酸化物の面心立方格子の原子最稠密方向 [110] が Ba の體心立方格子の最稠密方向 [111] と大體 本行になるものであり，Meh I(21)等が $\mathrm{Fe}$ 上に作つた $\mathrm{FeO}$ の方向性と類似したものであつて，即ち Ba 格子が一稜の 方向に伸びて正方對梅を持つようになり，格子中に O原子

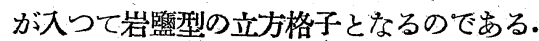

$\mathrm{Pb}$ の酸化物については Bragg と Darbyshire(E5) が ・oop 法により $\mathrm{ZnO}$ 及び $\mathrm{SnO}_{2}$ と共に $\mathrm{PbO}_{2}$ を得たが,

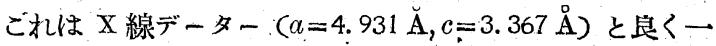
致する正方晶であり (100) 面を膜面に平行にする方向性を

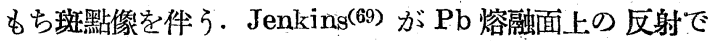
調べた $\mathrm{PbO}$ は斜方晶であつて $a=5.50 \AA$. $5.88 \AA$ の格子常嘍をもち，その $(001)$ 面を表面に平行に し金屬を徐々に㠜固せしめると酸化物の單結晶像力得られ た. Pbọの X線データーは $a=3.98 \mathrm{~A}, c=5.01 \mathrm{~A}$ の正方 晶である.な特 Wood の放電管による原子狀水素で還元

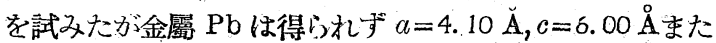
は $a=3.85 \AA, c=13.30 \AA$ の體心正方晶の迴折像か得られ た。

Darbyshire 己 Cooper(32) カ熔融 Bi から loop 洗で得 た $\mathrm{Bi}_{2} \mathrm{O}_{3}$ 薄膜は椱雜な 盂折像を示し，まる場合には $a=$ 16.85 A の體心立才格子の上うに思われるが，一般的に複 雜灭迴折像を說明するためには歪を受けた體し立方格子即 ち $c / a=1.04, a=10.85 \AA$ の體心正方格子と考えるべきで あうてこれは $\mathrm{Y}_{2} \mathrm{O}_{3}$ の構造と類似している. 然るに Jenkins ${ }^{(69)}$ 力熔融 $\mathrm{Pb}$ 面の反射から調べた所では $(001)$ 面を表面に平行にした $a=4.02 \AA ⿻$ 行 $c=6.30 \AA$ の六方晶であ

(72) W. G. Burgers and J. J. A. P. van Amstel, Physica, 3 (1936), 1057.
り, 取り出した膜の透過では $a=3.93 \mathrm{~A}, c / a=1.56$ の稠密 六方構造を得た 反射と透過とで常數の價が巽なるのは反 射の場合はカメラ中で撮影したものであるから熱膨脹を起 しているためと思われる. $\mathrm{Pb}, \mathrm{Bi}$ 等の酸化物の構造が, 各 研究者によつてまちまちであり，末た X 線データーとも 喰い違うのは薄膜の場合に下地金屬よりの影響で “假晶” を生じ易いためと考えられる.

$\mathrm{W}, \mathrm{Mo}$ 等の難傛融金屬の 酸化物は上田と紀本 (73) ガ亞 鉆悠と同樣な方泆で研究を行つた．透過の場合には煙を $\mathrm{Ni}$ 網に受け，反射の場合には黃銅盤に蒸着せしめた。加 熱盜度を $1700 \sim 1900^{\circ} \mathrm{K}$ に保つ場合には，W では氣壓か; $760 \mathrm{~mm} \mathrm{Hg}$ より $1 \mathrm{~mm} \mathrm{Hg}$ に減少するに應じて煙の色は 白 $\rightarrow$ 灰 $\rightarrow$ 青 $\rightarrow$ 水色に變化し，迴折環もこれに從つて Dabye 環けぼやけた環 酸化物は $\mathrm{WO}_{3}$ である. Mo の場合には氣壓が $760 \rightarrow 1 \mathrm{~mm}$ $\mathrm{Hg}$ と低下するに從い色は白 $\rightarrow$ 青色に變化し $\mathrm{MoO}_{3}$ の結晶 粒が次第に細かくなる。 またWの場合に氣壓を $5 \mathrm{~mm} \mathrm{Hg}$ に保持寸ると，溫度が $1350^{\circ} \rightarrow 2500^{\circ} \mathrm{K}$ と上昇するに從い，

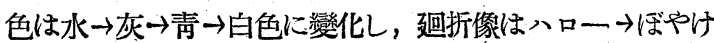
た環 $\rightarrow$ Debye 環となる。

$\mathrm{Ti}$ 及び Zr の酸化物及びこれ等と $\mathrm{Ni}, \mathrm{Cu}, \mathrm{Co}$ 等との合 金の酸化物は Hicirmann そ Gulbransen(74) が 300〜700。 の範圍で詳細に研究した. Ti 耐酸化性が强くが耐酸性も優秀であつて，これ等兩金屬 に関寸る最近の治金學には多大の進步が伺われ，Ti は高 溫度下のガスタービy用の合金に，また Z $\mathrm{r}$ は高溫度發生 用の合金成分に用いられている. 兩金屬共に䧼傛融酸化物 を作り，しかも $500^{\circ}$ 以上では兩金屬共に耐酸化性でない。 彼等の使用した試料は圓杜形で良く鹰いた後にカメラ中で 酸素によつて酸化させて反射寫自を撮り，これを下地か

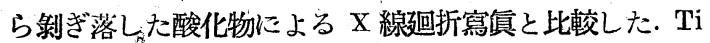
の酸化については $700^{\circ}$ に㧤いて正方晶采に屬する rutile 構造を有する $\mathrm{TiO}_{2}$ が見出されたが, これは $915^{\circ}$ 以下では anatase 構造が安定であるとの在來の定說に反する，金犀 下地の存在に影響することもあるので 200 メッシュの Ti 粉末を酸化させたが矢張り Rutile 構造を有すしていた。 $\mathrm{Zr}$ を $500^{\circ}$. て酸化させると單科晶系に屬する $\mathrm{ZrO}_{2}$ が得ら れるがこれは表面に密着して剝げ難い. 恐らく $\mathrm{Zr}$ が $\mathrm{O}_{2}$ を多量に溶解する性質があるために金屬酸化物の 固溶體 を生じているためと思われる． $\mathrm{ZrO}_{2}$ には他に立方，正方 晶系に屬する 2 變態があるがこれ等は見出されなかつた。 次に $50 \mathrm{Ti}-\mathrm{Ni}, \pi \mathrm{Ti}-\mathrm{Ni}, 28 \mathrm{Ti}-\mathrm{Cu}$ 等の合金を. $700^{\circ}$ で酸 化させると，いず礼の場合にも表面酸化物は $\mathrm{TiO}_{2}$ であつ た. 前二者は $700^{\circ}$ 迄の溫度では良好な耐酸化性を示し， いずれも $\mathrm{NiO}$ を生ぜず Ti イオンの生成及び擴散速度が $\mathrm{Ni}$ イオンのそれ等より大なることを示す．28 Ti-Cu の $500^{\circ}$ 以ドの酸化では $\mathrm{Cu}$ イオンが表面に擴散し, $\mathrm{Cu}_{2} \mathrm{O}$ 被

(73) 上田良二，紀本和男，應用物理，18 (1949/50),256，

(74) J. W. Hickman and E. A. Gulbransen, Anal.' Chem., 20 (1948), 158. 
膜を生ずる. $/ \mathrm{Zr}$ 合金の中 $20 \mathrm{Zr}-\mathrm{Cu}$ では酸化被膜の上層 に $\mathrm{CuO}$, 下層に $\mathrm{Cu}_{2} \mathrm{O}$ を生じ短時閒の酸化で容易に Scale をつくる. $60 \mathrm{Zr}-\mathrm{Co}, 70 \mathrm{Zr}-\mathrm{Ni}$ では究れぞれ $\mathrm{Co}_{3} \mathrm{O}_{4}$ 及び $\mathrm{NiO}$ を生じた. 後者は $500^{\circ}$ 以上の溫度で表面被膜に $\mathrm{NiO}$ を生ずる唯一の $\mathrm{Ni}$ 合金である. 以上 3 種類の $\mathrm{Zr}$ 合金で は熱力學的データーはいずれの場合にも $\mathrm{ZrO}_{2}$ の生成を意 味するものであつた. 以上の結果から見ると Ti イオンの 生成並に擴散速度は $\mathrm{Zr}$ イオンのそれ等よりも大なるよう に思われる。

最後に $\mathrm{Mg}$ の酸化について述べる. Finch とQuarrell

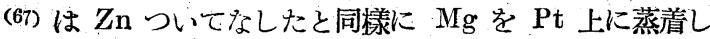
て酸化させ反射法で調べたが， $a=2.99 \AA, c / a=1.55$ の六 方晶系のものを得た。これは bulk の金屬に欮ける $\mathrm{x}$ 線 データーの示す岩監型の立方構造ではない。こ札は $\mathrm{Zn} に$ 特けると同樣一種の “假晶”であつて $\mathrm{MgO}$ が生長する場 合に金屬 Mg の影響により その六方配置を保持するよう な歪力の作用の下に異常構造の發達を見たのであつて勿 論あまり厚さが大でない範園の問題である。Darbyshire そ Gooper (32) は他の金屬と同樣に熔融 $\mathrm{Mg}$ 上から $\mathrm{ZnCl} 2$ を flux として酸化物薄膜を得た。これは方向性を有しな
い $a=4.19 \mathrm{~A}$ の岩㽉型 $\mathrm{MgO}$ であつた.この格子常數は X線データーと大體一致するがその測定强度は計算と一致 しない. Mg の酸化に関しては他に飯高一山口(75),山口(76) の研究がある. $\mathrm{Mg}$ の上うな輕金屬で良好な反射迴折像を 得るには表面をあまり平滑にずることなく，相當粗いメメ リー紙で磨いただけの方が却つて迴折に好適な表面が得ら れることが指摘されている．輕金屬では電子の彈性散亂的 透過距離が堙加するために表面小突起が相當大であつてか まわないためである. 室溫に抽る $\mathrm{Mg}$ の表面には $\mathrm{Mg}$ 環の外に $\mathrm{MgO}$ の最强の二環即方 (200), (220) 朵加すか に現われ，空氣中 $400^{\circ}$ の酸化では $\mathrm{MgO}$ 環の外に $\mathrm{Mg}$ の最强環 (101) がか寸加見られる. 即ち $\mathrm{MgO}$ 被膜は $400^{\circ}$ の酸化でも下地金屬の迴折環が現われる程薄く大體. 〜10 A 程度の厚さを有するに過ぎないと推定される.な 特 Be の堂溫放置の表面には $\mathrm{BeO}$ の廻折環は見出されな かつた。

(つッ゙く)

(75) I. Titaka and S. Yamaguchi, Nature, 144 (1939),1090.

(76) S. Yamaguchi， Sci. Pap. I. P.C. R. Tokyo, 36 (1939),463.

\section{齒、科 用 金 屬材 料 (III)}

\section{\%. 糊}

例えば，義莮床のよ弓に，日腔内の微細な四凸部によ～ 密着しなければならない場合の成形は，加工（スクイージ ング)によつでも出來ないことはないが，精密鑄造による 方が簡單でもあり, 正確であある. 從つてインー，義莮 床，バー等には鑄造材が好んで用いられる。 またクラスプ も彈性限の高い鑄造材があれば，鑄造によつて成形寸る方 が便利でせる。

齿科精密鑄造法の詳細は，後述するが，吾國では各齒科 醫が夫々自家技工室でこれを行引関係上，高熔融點金屬の 熔解は困蜼で，せいぜいガスバーナーで熔解し得る程度即 ち $1100^{\circ}$ 以下普通 $1000^{\circ}$ 以下のものが望まれる。.しがし がら鑞着の関係で, 餘り熔骶點の低い金屬も不可である. 從つて篙造材としては, 愹融點 800〜 $1000^{\circ}$ の範園內のも のか理想的であるとされている，その他，無論流動性がよ くなければならないし，收縮萑は後述する埋沒劑の関係で， $1.5 \%$ 以下であることが必要である. 耐創性, 耐色性共に 優秀でなければならないこと勿論である. このような多く の條件を完全に具有した金屬材料は少ない，たが金基合金 か略、滿足すべき材料として古くからこの目的に使用され ている.

* 東北大學㸚授; 金屬材料研究所

** 東北大學助手; 金屬材料研究所

\section{大日方一司*山路賢吉**}

1930 年瑱から，銀ーパラデウム系の合金が使用され始 め，現在で金合金に匹敵する優秀な鑄造用合金として，

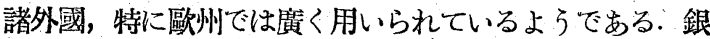
に亞鉛，カドミウム，錫，インデウム等を加えた合金は， 耐蝕性の點で蜼點はむるが，吾國では一部使用されてい る.

コバルトークロム系の合金は，既に述べたように，米國 では金基合金に優る優秀な鑄造用合金として廣く使用され てるるが，吾國では，尔の高熔融點 $\left(1400^{\circ}\right.$ 前後) のため に，適當な埋沒劑がなく，未だ使用されるに到らない。

吾國で，最近貴金屬の使用が困䧼なために、ニッヶル 一銅一亞鉛系の鑄造用合金が廣く使用されているが，矿蝕 性及び機械的性質の上で完全なむのは少ない。最近篗者等 は，この系に屬する廣い、範園の合金の諸性質を追求し，稍 々滿足すべきものを得たがその詳細については別に報告す $ろ^{(13)}$.

\section{2. 踩科精密偣造法}

現在行われている齒科精密鑄造法は, 1907 年 William Taggart により, Lost Wax Process として考案された

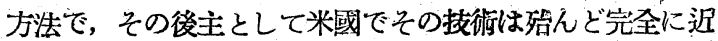
い域に迄改善されている. 最迟工業の方面にも，この原理 ガ取り入れられて，所謂 Investment Casting として,

（13）本會昭和24年11月及び昭和26年 4 月の大會に發表 